\title{
Spinal and cutaneous schwannomatosis is a variant form of type 2 neurofibromatosis: a clinical and molecular study
}

D Gareth R Evans, Susan Mason, Susan M Huson, Margaret Ponder, the late A E Harding, Thomas Strachan

\begin{abstract}
Objective-To delineate the clinical phenotype, molecular basis, and implications for screening in patients and families with multiple schwannomas not generally involving the cranium.

Methods-As part of a United Kingdom clinical and genetic study of type 2 neurofibromatosis (NF2) patients and families with multiple schwannomas who do not fulfil diagnostic criteria for NF2 have been identified. The clinical phenotype was studied in the extended families and molecular analysis was carried out at the

Table 1 Diagnostic criteria for NF1 and NF2

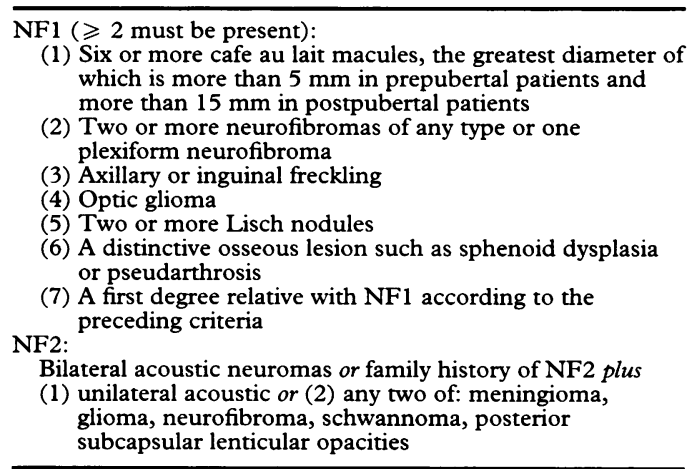
NF2 gene locus on chromosome 22.

Results-Patterns of inheritance in five families with schwannomatosis are consistent with inheritance of an autosomal dominant gene. The consistency of phenotype, with relative sparing of the cranium, is constant in these families. However, families which initially seem to be indicative of schwannomatosis may develop into classic NF2 as shown by a sixth family. Many of the tumours found in these families were referred to as "neurofibroma" when they were clearly schwannomas. This difference in classification has major implications for the relative risk of each particular type of neurofibromatosis and neuropathological review may be important in some cases. Genetic linkage analysis in the two largest families is entirely consistent with primary involvement of the NF2 gene.

Conclusions-Variant forms of neurofibromatosis have presented a dilemma in classification and determination of recurrence risks in families. Previous reports have suggested that schwannomatosis is a sporadic non-hereditary condition. Patients with multiple schwannomas are likely to have a variant form of NF2 and up to a $50 \%$ risk of passing on a gene predisposing to multiple schwannoma.

(F Neurol Neorosurg Psychiatry 1997;62:361-366)

Keywords: neurofibromatosis; schwannomatosis; schwannoma; meningioma; spinal tumour

The neurofibromatoses consist of at least two distinct dominantly inherited disorders: neurofibromatosis type 1 (NF1) and NF2. These conditions were eventually recognised as separate entities with the localisation of the respective genes to chromosome 17 and 22 , and with the NIH consensus statement in $1987 .^{1-3}$ None the less there are many patients and indeed some families who do not fulfil NIH criteria for NF1 or NF2 (table 1). This has led various authors to speculate on there being up to six other types of neurofibromatosis. ${ }^{45}$ Two entities which have been suggested as separate forms of NF are: familial spinal NF, NF4 and schwannomatosis. ${ }^{45}$ Most reports of patients with multiple cutaneous and or spinal schwannomas emphasise that these cases are usually sporadic, ${ }^{4-6}$ and that indeed they may not represent a hereditary condition. Our experience with six families and seven sporadic cases of schwannomatosis leads us to think that this is a true genetic entity and that it is likely in most instances to be a variant form of NF2. We present here the clinical features and molecular analysis of these families and sporadic cases.

\section{Case reports}

FAMILIAL CASES

Figures 1 and 2 show the pedigrees of the two largest families and table 2 shows a clinical summary.

\section{Family $M$ (fig 1)}

The proband II- 3 presented aged 25 years with a subcutaneous lump which was removed. He underwent three further excisions of subcutaneous tumours between 50 and 54 years of age. He then presented with foot drop and was found to have two tumours at L4-5. Both these proved to be schwannomas. Finally aged 65 years he had a schwannoma removed from his left hand. His brother II-1 has had six subcutaneous tumours removed at various intervals from the age of 21 years. Several of these were associated with major nerves (femoral, brachial plexus). All were reported as neurilemmoma or neuri- 


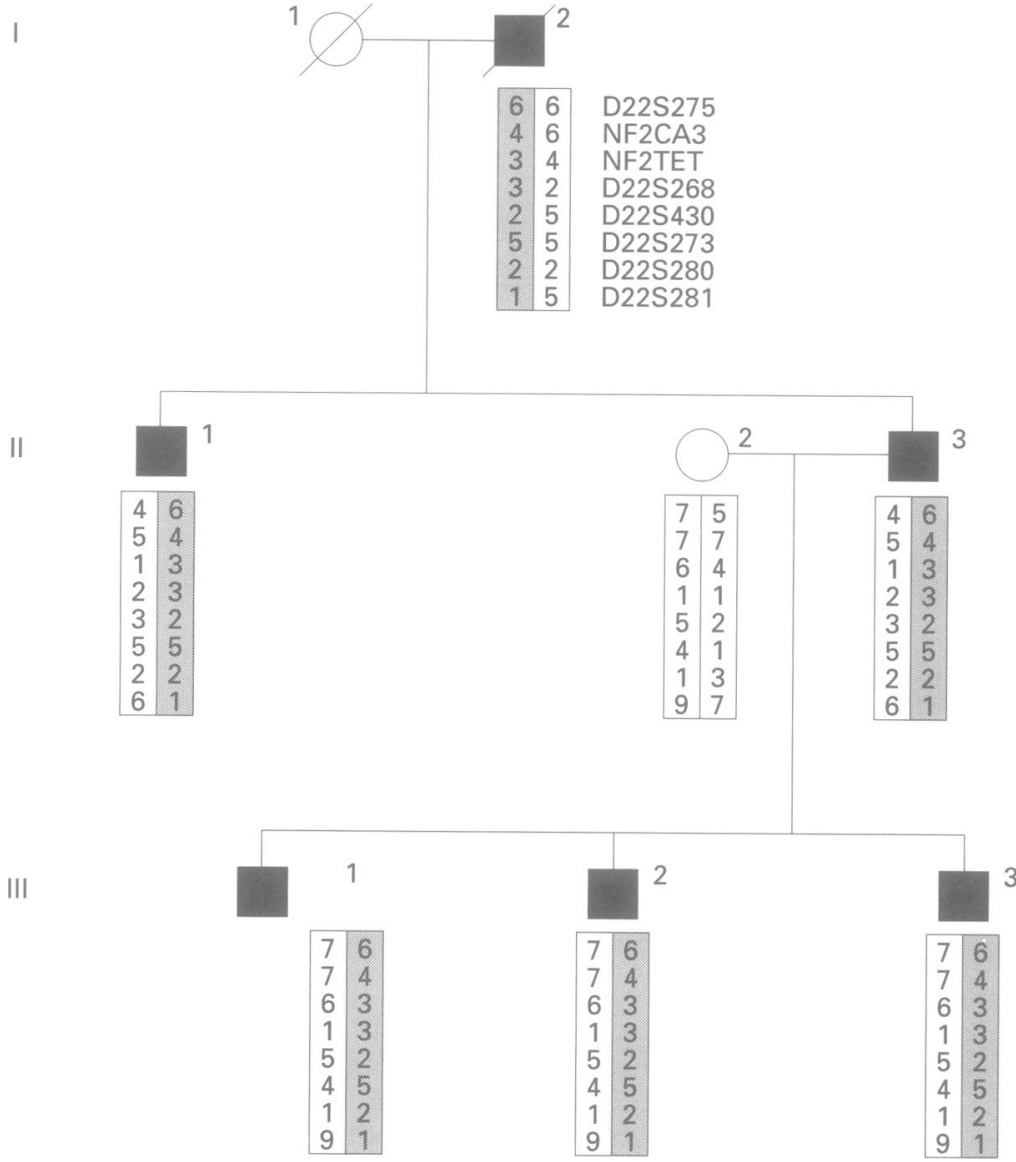

Figure 1 Haplotype analysis of schwannomatosis family $M$. Shaded boxes represent a haplotype that is inferred to segregate with the disease.

noma. Proband II-1 has complained of hearing loss for several years, but this improved substantially after stapedectomy. All three of II-3's sons had had a cutaneous schwannoma/neurilemmoma removed. In addition III-3 had an S1 schwannoma removed when aged 31 . More recently he complained of unilateral tinnitus and MRI showed a right sided vestibular schwannoma, but no evidence of contralateral disease. Patients II-1 and III-1 were found to have lenticular opacities on ophthalmoscopy and I-2 was known to have had a longstanding cataract.
Family $C$ (fig 2)

The proband CII-2 presented aged 33 with a lump in her right ankle. She underwent routine preoperative chest radiography, which showed a right sided mediastinal mass. At thoracotomy a cystic mass was removed posteriorly. This mass and the ankle tumour were reported as "neurilemmoma". Three years later two tumours were removed from the left sternomastoid, which were reported as "neurofibromata", yet the report states that they were "very similar" to the previous specimens. She had no further problems until the age of 61 when she developed tingling and weakness in her lower limbs. A myelogram showed a tumour at Ll which was excised (schwannoma). However, her symptoms remained and she underwent a further myelogram which showed cord compression from C5-T1. Exploration disclosed an inoperable meningioma encircling the cord, with an adjacent schwannoma. She died 12 months after her final spinal surgery. She had two deep subcutaneous tumours in her right forearm and left heel consistent with schwannomas. There were no other cutaneous findings and she had no cataracts or Lisch nodules on slit lamp examination.

The father of II-2 died aged 62 having had spinal tumours and an intrathoracic tumour removed. His death certificate stated that he had "multiple neurofibromata". A paternal uncle and aunt were also said to have had spinal tumours removed. Family members II3, II-5, and II-7 all had spinal tumours diagnosed and all had deep cutaneous tumours. Patient II- 3 presented aged 37 with deafness and headache and had a left cerebellopontine angle tumour removed. This came from the spinal accessory nerve and was reported as a "neurofibroma". Three years later he underwent removal of a further "neurofibroma" at L1-2 and aged 64 had a schwannoma removed from C5-6. Finally a schwannoma was removed from T12 when he was aged 65 . Although he has recently complained of deafness cranial CT was normal. Patient II-5 had three small asymptomatic spinal tumours on MRI and three large subcutaneous tumours.
Figure 1 Haplotype analysis of

schwannomatosis family C. The haplotypes shown are for the polymorphic DNA markers D22S275, NF2CA3, NF2TET $D 22 S 268, D 22 S 430$ D22S273, D22S280, and D22S281. Shaded boxes represent a haplotype inferred to segregate with the disease.

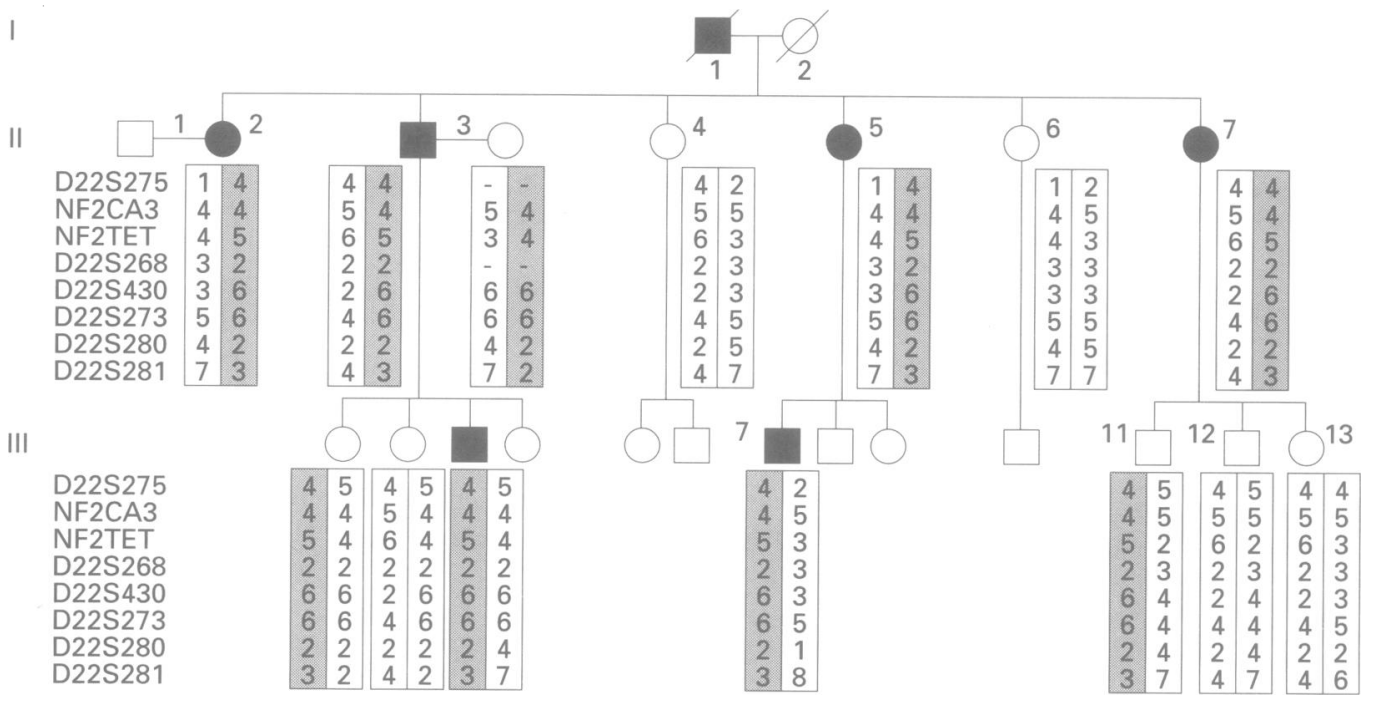


Table 2 Onset of symptoms and site of tumours in familial cases of schwannomatosis

\begin{tabular}{|c|c|c|c|c|c|c|c|c|c|}
\hline \multirow[b]{2}{*}{ Case } & \multicolumn{2}{|c|}{ Age (y) } & \multicolumn{3}{|c|}{ Schwannomas (n) } & \multirow[b]{2}{*}{ Deafness } & \multirow{2}{*}{$\begin{array}{l}\text { Cranial } \\
\text { scan }\end{array}$} & \multirow[b]{2}{*}{ Cateract } & \multirow[b]{2}{*}{ Cal } \\
\hline & Now & Symptoms & Spinal & Cutaneous & Cranial & & & & \\
\hline $\begin{array}{l}\text { CI-1 } \\
\text { CII-2 } \\
\text { CII-3 }\end{array}$ & $\begin{array}{r}\geqslant 62 \\
\geqslant 65 \\
67\end{array}$ & $\begin{array}{l}\text { NK } \\
33 \\
37\end{array}$ & $\begin{aligned} \geqslant & 2 \\
& 3 \dagger \\
& 2\end{aligned}$ & $\begin{array}{l}1 \neq \\
6 \neq \\
4\end{array}$ & \multirow{2}{*}{$\begin{array}{l}\text { NK } \\
\text { No } \\
1 \\
\text { IX } \\
\text { No } \\
\text { No } \\
\text { No } \\
\text { No }\end{array}$} & $\begin{array}{l}\text { No } \\
\text { No } \\
\text { Yes }\end{array}$ & $\begin{array}{l}\text { No } \\
\text { No } \\
\text { Yes }\end{array}$ & $\begin{array}{l}\text { No } \\
\text { No } \\
\text { No }\end{array}$ & $\begin{array}{l}\text { NK } \\
\text { No } \\
\text { No }\end{array}$ \\
\hline $\begin{array}{l}\text { CII-5 } \\
\text { CII-7 } \\
\text { CIII-3 } \\
\text { CIII-7 }\end{array}$ & $\begin{array}{l}61 \\
58 \\
30 \\
35\end{array}$ & $\begin{array}{l}59 \\
54 \\
\text { No } \\
\text { No }\end{array}$ & $\begin{array}{l}3 \\
2 \\
1 \\
0\end{array}$ & $\begin{array}{l}4 \\
1 \\
0 \\
1\end{array}$ & & $\begin{array}{l}\text { No } \\
\text { No } \\
\text { No } \\
\text { No }\end{array}$ & $\begin{array}{l}\text { No } \\
\text { Yes } \\
\text { Yes } \\
\text { No }\end{array}$ & $\begin{array}{l}\text { No } \\
\text { No } \\
\text { No } \\
\text { No }\end{array}$ & $\begin{array}{l}\text { No } \\
\text { No } \\
\text { No } \\
\text { No }\end{array}$ \\
\hline $\begin{array}{l}\text { MI-2 } \\
\text { MII-1 } \\
\text { MII-3 }\end{array}$ & $\begin{array}{r}\geqslant 93 \\
62 \\
64\end{array}$ & $\begin{array}{l}\text { NK } \\
21 \\
25\end{array}$ & $\begin{array}{r}\text { NK } \\
0 \\
2\end{array}$ & $\begin{array}{c}\geqslant 1^{\star} \\
6 \\
4\end{array}$ & $\begin{array}{l}\text { No } \\
\text { No } \\
\text { No }\end{array}$ & $\begin{array}{l}\text { Yes } \\
\text { Yes } \\
\text { No }\end{array}$ & $\begin{array}{l}\text { No } \\
\text { No } \\
\text { No }\end{array}$ & $\begin{array}{l}\text { Yes } \\
\text { Yes } \\
\text { No }\end{array}$ & $\begin{array}{l}\text { NK } \\
\text { No } \\
\text { No }\end{array}$ \\
\hline MIII-1 & 37 & 24 & 1 & 4 & $\begin{array}{l}1 \\
\text { VIII }\end{array}$ & No & Yes & No & No \\
\hline $\begin{array}{l}\text { MIII-2 } \\
\text { MIII-3 }\end{array}$ & $\begin{array}{l}39 \\
33\end{array}$ & $\begin{array}{l}23 \\
19\end{array}$ & $\begin{array}{l}0 \\
0\end{array}$ & $\begin{array}{l}1 \\
1\end{array}$ & $\begin{array}{l}0 \\
0\end{array}$ & $\begin{array}{l}\text { No } \\
\text { No }\end{array}$ & $\begin{array}{l}\text { No } \\
\text { No }\end{array}$ & $\begin{array}{l}\text { Yes } \\
\text { No }\end{array}$ & $\stackrel{1}{\text { No }}$ \\
\hline $\begin{array}{l}\text { D101 } \\
\text { D201 }\end{array}$ & $\begin{array}{l}68 \\
31\end{array}$ & $\begin{array}{l}16 \\
18\end{array}$ & $\begin{array}{l}3 \\
1\end{array}$ & $\begin{array}{l}0 \\
0\end{array}$ & $\begin{array}{l}0 \\
0\end{array}$ & $\begin{array}{l}\text { No } \\
\text { No }\end{array}$ & $\begin{array}{l}\text { Yes } \\
\text { Yes }\end{array}$ & $\begin{array}{l}\text { No } \\
\text { No }\end{array}$ & $\begin{array}{l}\text { No } \\
\text { No }\end{array}$ \\
\hline $\begin{array}{l}\text { S201 } \\
\text { S202 }\end{array}$ & $\begin{array}{l}45 \\
58\end{array}$ & $\begin{array}{l}23 \\
22\end{array}$ & $\begin{array}{l}0 \\
4\end{array}$ & $\begin{array}{l}3 \\
2\end{array}$ & $\begin{array}{l}0 \\
1 \\
\text { IX }\end{array}$ & $\begin{array}{l}\text { No } \\
\text { No }\end{array}$ & $\begin{array}{l}\text { Yes } \\
\text { Yes }\end{array}$ & $\begin{array}{l}\text { No } \\
\text { No }\end{array}$ & $\begin{array}{l}\text { No } \\
\text { No }\end{array}$ \\
\hline $\begin{array}{l}\text { S203 } \\
\text { S204 }\end{array}$ & $\begin{array}{l}\geqslant 33 \\
\geqslant 37\end{array}$ & $\begin{array}{l}20 \\
\mathrm{NK}\end{array}$ & $\begin{array}{l}7 \\
1\end{array}$ & $\begin{array}{l}\text { NK } \\
\text { NK }\end{array}$ & $\begin{array}{l}0 \\
0\end{array}$ & $\begin{array}{l}\text { No } \\
\text { No }\end{array}$ & $\begin{array}{l}\text { No } \\
\text { No }\end{array}$ & $\begin{array}{l}\text { NK } \\
\text { NK }\end{array}$ & $\begin{array}{l}\text { NK } \\
\text { NK }\end{array}$ \\
\hline $\begin{array}{l}\text { Ma101 } \\
\text { Ma202 }\end{array}$ & $\begin{array}{l}37 \\
20\end{array}$ & $\begin{array}{l}20 \\
18\end{array}$ & $\begin{array}{l}6+ \\
1\end{array}$ & $\begin{array}{r}10 \\
1\end{array}$ & $\begin{array}{l}0 \\
0\end{array}$ & $\begin{array}{l}\text { No } \\
\text { No }\end{array}$ & $\begin{array}{l}\text { No } \\
\text { Yes }\end{array}$ & $\begin{array}{l}\text { NK } \\
\text { NK }\end{array}$ & $\stackrel{2}{\text { No }}$ \\
\hline
\end{tabular}

«No historical confirmation available; tmeningioma; łextraspinal intrathoracic tumour requiring thoracotomy; VIII and XI = cranial nerve schwannoma; NK = not known; Cal = cafe au lait patches.

Patient II-7 had two spinal schwannomas removed, but recent cranial MRI was normal. There were no intracutaneous tumours in any member of the family and no evidence of Lisch nodules or cataract on slit lamp examination.

Families D, S, and Ma

Table 2 shows the summaries of these families. Family D consists of an affected father and son, family $S$ contains four affected siblings, and family $\mathrm{Ma}$ an affected mother and son. The pattern of tumours in these families was very similar to families $M$ and C. Again some confusion existed over the terminology of the tumours removed. These ranged from neurofibroma through neurilemmoma to schwannoma.

\section{Family $V$}

The proband presented aged 17 with muscle wasting. She has since had four spinal schwannomas and a cervical spinal ependymoma removed surgically. She denied hearing loss when aged 38, but had no cranial imaging for more than 10 years. Her brother presented aged 27 in the same year as his sister with numbness and pain in his left leg. Eventually five years later a large tumour attached to the sciatic nerve was removed and reported as a neurilemmoma. Four years later he had a thoracotomy for two opacities noticed on chest radiography. Both tumours were reported as neurilemmoma. He then presented aged 41 years with a tumour at T11, which again proved to be neurilemmoma. It was not until the age of 44 years that he noticed some hearing loss and one year later bilateral vestibular schwannoma were diagnosed.

His son had undergone craniotomy aged 10 for a cranial meningioma which induced seizures. After his father's diagnosis he underwent MRI when aged 22 which showed bilateral vestibular schwannoma and a further meningioma. There was a suggestive history of NF2 in the father of the proband as he had three skin lumps and unilateral hearing loss before his death from lung cancer aged 57 years. The paternal uncle was also deaf and the paternal grandmother was said to have died from a brain tumour at the age of 30 years. All the living affected cases had easily identifiable lens opacities, but no cafe au lait patches or Lisch nodules. It is clear that this family has classic NF2. However, between the diagnosis of the original tumours in the proband and her brother and the diagnosis of bilateral vestibular schwannoma in the brother some 19 years later their disorder could have been classified as schwannomatosis.

SPORADIC CASES

Table 3 shows seven sporadic cases with three

Table 3 Onset of symptoms and site of tumours in sporadic cases of schwannomatosis

\begin{tabular}{|c|c|c|c|c|c|c|c|c|c|}
\hline \multirow[b]{2}{*}{ Case } & \multicolumn{2}{|c|}{ Age (y) } & \multicolumn{3}{|c|}{ Schwannomas (n) } & \multirow[b]{2}{*}{ Deafness } & \multirow{2}{*}{$\begin{array}{l}\text { Cranial } \\
\text { scan }\end{array}$} & \multirow[b]{2}{*}{ Cataract } & \multirow[b]{2}{*}{$\mathrm{Ca}$} \\
\hline & Now & Symptoms & Spinal & Cutaneous & Cranial & & & & \\
\hline $\begin{array}{l}1 \\
2 \\
3 \\
4 \\
5 \\
6 \\
7\end{array}$ & $\begin{array}{l}64 \\
43 \\
39 \\
54 \\
40 \\
41 \\
55\end{array}$ & $\begin{array}{l}54 \\
23 \\
19 \\
12 \\
38 \\
29 \\
42\end{array}$ & $\begin{array}{c}1 \\
0 \\
0 \\
3 \\
3 \\
>10 \\
2+\end{array}$ & $\begin{aligned} & 4 \\
& 4 \ddagger \\
& 3 \\
& 6 \\
& 1 \\
& 0 \\
& 0\end{aligned}$ & $\begin{array}{l}0 \\
0 \\
0 \\
0 \\
0 \\
0 \\
0\end{array}$ & $\begin{array}{l}\text { No } \\
\text { No } \\
\text { No } \\
\text { No } \\
\text { No } \\
\text { No } \\
\text { No }\end{array}$ & $\begin{array}{l}\text { Yes } \\
\text { Yes } \\
\text { Yes } \\
\text { Yes } \\
\text { Yes } \\
\text { Yes } \\
\text { Yes }\end{array}$ & $\begin{array}{l}\text { Yes } \\
\text { No } \\
\text { No } \\
\text { No } \\
\text { No } \\
\text { NK } \\
\text { NK }\end{array}$ & $\begin{array}{l}1 \\
1 \\
0 \\
0 \\
0 \\
0 \\
0\end{array}$ \\
\hline
\end{tabular}

$\star$ Footnotes as for table 2 
or more schwannomas, but insufficient criteria for NF2. There are no features suggestive of schwannomatosis in any other family member.

\section{Methods for molecular analysis}

Genomic DNA was prepared from blood samples using standard methods. ${ }^{7}$ Radioactive polymerase chain reaction (PCR) was performed on 50-200 ng of genomic DNA from each family member, to amplify individual microsatellite markers. The markers were D22S275, ${ }^{8}$ NF2CA3, ${ }^{9}$ NF2TET (previously unpublished tetranucleotide AAAAG marker in intron 1 of the NF2 gene (forward primer-ACCACTGCACTCCAGCCTGG; reverse primer-TATGCCATGTTCTTGTTGAAGG; product size $160-174$ bp)), D22S273, ${ }^{8}$ D22S268, ${ }^{10}$ D22S430, ${ }^{11}$ D22S281, ${ }^{8}$ D22S280. ${ }^{8}$ The forward primer was radioactively labelled at the $5^{\prime}$ terminus with $\gamma^{32} \mathrm{P}$ ATP using standard procedures and PCR reactions were carried out in a reaction volume of $10 \mu \mathrm{l}$ Tbr polymerase (NBL Gene Sciences) according to the manufacturer's instructions. Samples were thermocycled on a PCR480 Perkin Elmer Cetus thermal cycler machine for 30 cycles of $95^{\circ} \mathrm{C}$ for one minute, annealing at the appropriate temperature ${ }^{8-11}$ for one minute, and $72^{\circ} \mathrm{C}$ for one minute followed by a final elongation step at $72^{\circ} \mathrm{C}$ for 10 minutes. With the exception of D22S430, which was denatured and annealed for 30 seconds and extended for 90 seconds and NF2TET which was denatured and annealed for 90 seconds and an extension of 30 seconds. Products from PCR were electrophoresed on $6 \%$ denaturing polyacrylamide gels and viewed by autoradiography on Kodak X-Omat AR film.

Linkage analysis was performed with data management package LINKSYS in conjunction with the computer programme LINK-

Table 4 Lod score table for two point linkage analysis of families with Schwannomatosis and chromosome $22 q 12 \cdot 2$ markers

\begin{tabular}{|c|c|c|c|c|c|c|c|c|}
\hline \multirow[b]{2}{*}{ Locus } & \multirow[b]{2}{*}{ Family } & \multicolumn{7}{|c|}{ Recombination fraction $\Theta$} \\
\hline & & $0 \cdot 0$ & 0.01 & 0.05 & $0 \cdot 1$ & $0 \cdot 2$ & $0 \cdot 3$ & 0.4 \\
\hline \multirow[t]{2}{*}{$D 22 S 275$} & $\begin{array}{l}C \\
M\end{array}$ & $\begin{array}{l}1.45 \\
0.90\end{array}$ & $\begin{array}{l}1.42 \\
0.89\end{array}$ & $\begin{array}{l}1.29 \\
0.84\end{array}$ & $\begin{array}{l}1 \cdot 13 \\
0.77\end{array}$ & $0 \cdot 79$ & 0.42 & $0 \cdot 11$ \\
\hline & $C+M$ & $2 \cdot 35$ & $2 \cdot 31$ & $2 \cdot 13$ & 1.90 & $\begin{array}{l}0.01 \\
1.40\end{array}$ & $\begin{array}{l}0.44 \\
0.86\end{array}$ & $\begin{array}{l}0.24 \\
0.35\end{array}$ \\
\hline \multirow[t]{3}{*}{$N F 2 C A 3$} & C & 0.78 & 0.76 & 0.68 & 0.58 & 0.38 & $0 \cdot 19$ & 0.05 \\
\hline & M & $1 \cdot 20$ & 1.18 & 1.09 & 0.98 & 0.75 & 0.50 & 0.25 \\
\hline & $C+M$ & 1.99 & 1.95 & 1.78 & 1.56 & $1 \cdot 13$ & 0.69 & 0.30 \\
\hline \multirow[t]{3}{*}{ NF2TET } & C & $1 \cdot 68$ & 1.65 & 1.51 & $1 \cdot 34$ & 0.95 & 0.53 & $0 \cdot 15$ \\
\hline & M & $1 \cdot 20$ & $1 \cdot 18$ & 1.09 & 0.98 & 0.75 & 0.50 & 0.25 \\
\hline & $C+M$ & $2 \cdot 88$ & $2 \cdot 83$ & $2 \cdot 61$ & $2 \cdot 32$ & $1 \cdot 70$ & 1.03 & 0.40 \\
\hline \multirow[t]{3}{*}{$D 22 S 268$} & C & 0.57 & 0.56 & 0.51 & 0.44 & $0 \cdot 30$ & $0 \cdot 16$ & 0.05 \\
\hline & M & $0 \cdot 82$ & $0 \cdot 80$ & 0.72 & 0.62 & 0.41 & 0.21 & 0.06 \\
\hline & $\mathrm{C}+\mathrm{M}$ & $1 \cdot 40$ & 1.36 & $1 \cdot 23$ & 1.06 & 0.71 & 0.37 & $0 \cdot 11$ \\
\hline \multirow{3}{*}{$D 22 S 430$} & C & $1 \cdot 38$ & 1.35 & $1 \cdot 23$ & 1.08 & $0 \cdot 75$ & $0 \cdot 40$ & 0.11 \\
\hline & M & $1 \cdot 20$ & $1 \cdot 18$ & 1.09 & 0.98 & 0.75 & 0.50 & $0 \cdot 25$ \\
\hline & $C+M$ & $2 \cdot 58$ & 2.53 & $2 \cdot 33$ & $2 \cdot 06$ & 1.50 & 0.91 & 0.36 \\
\hline \multirow[t]{3}{*}{$D 22 S 273$} & C & $1 \cdot 38$ & 1.35 & $1 \cdot 23$ & $1 \cdot 08$ & 0.75 & $0 \cdot 40$ & $0 \cdot 11$ \\
\hline & M & 0.00 & 0.00 & 0.00 & 0.00 & 0.00 & 0.00 & 0.00 \\
\hline & $C+M$ & $1 \cdot 38$ & 1.35 & $1 \cdot 23$ & 1.08 & 0.75 & 0.40 & 0.11 \\
\hline \multirow[t]{3}{*}{$D 22 S 280$} & C & 1.45 & 1.42 & $1 \cdot 29$ & $1 \cdot 13$ & 0.79 & 0.42 & $0 \cdot 11$ \\
\hline & $\mathbf{M}$ & 0.00 & 0.00 & 0.00 & 0.00 & 0.00 & 0.00 & 0.00 \\
\hline & $C+M$ & $1 \cdot 45$ & 1.42 & $1 \cdot 29$ & $1 \cdot 13$ & 0.79 & 0.42 & 0.11 \\
\hline \multirow[t]{3}{*}{$D 22 S 281$} & & $1 \cdot 68$ & 1.65 & 1.51 & $1 \cdot 34$ & 0.95 & 0.53 & $0 \cdot 15$ \\
\hline & & $1 \cdot 20$ & $1 \cdot 18$ & 1.09 & 0.98 & 0.75 & 0.50 & 0.25 \\
\hline & $C+M$ & $2 \cdot 88$ & $2 \cdot 83$ & $2 \cdot 61$ & $2 \cdot 32$ & $1 \cdot 70$ & 1.03 & 0.40 \\
\hline
\end{tabular}

Values represent pairwise lod scores between disease and indicated marker locus: linkage analysis was performed with the data management package LINKSYS in conjunction with the computer program LINKAGE version $5 \cdot 1$ : genetic distances between the 22q12.2 markers were taken to
be as follows: D22S275-1 cM - D22S273 - 2cM - D22S280-1cM - D22S281; NF2CA3 and be as follows: D22S275-1 cM - D22S273 - 2cM - D22S280 - 1cM - D22S281; NF2CA3 and
$N F 2 T E T$ are located within intron 1 of the NF2 gene; D22S268 and D22S430 are located in a $N F 2 T E T$ are located within intron 1 of the NF2 gene; D22S 268 ar
$160 \mathrm{~kb}$ contig, approximately $300 \mathrm{~kb}$ telomeric to the NF2 gene.
AGE version $5 \cdot 1$. The penetrance values used in linkage were as follows: $20 \%$ at 30 years; $35 \%$ at 35 years; $85 \%$ at 55 years; $93 \%$ at 60 years; and $95 \%$ at 70 years.

\section{Results}

Figures 1 and 2 show the results of linkage analysis in the two large multigenerational families ( $M$ and $C$ ). All affected people in both families shared the inferred disease haplotype, with no recombination between any of the markers. Individuals III-1 and III-11 in family C, however, have inherited the "disease" haplotype but are phenotypically normal. If they carry the disease gene they have as yet failed to manifest any signs of the disorder and are clear on craniospinal MRI. Both are comparatively young (38 and 37 years) and the penetrance values for this age range are assumed to be relatively low (see methods).

The two point linkage analysis between chromosome 22q12.2 markers and the schwannomatosis families are consistent with the possibility that the disorder in these families is linked to the NF2 locus (table 4). For all markers analysed $Z_{\max }$ is at zero recombination. The maximum lod score was obtained with the intragenic marker NF2TET $\left(Z_{\max }=\right.$ $2 \cdot 88$ ). Although the significant lod score of +3.00 was not achieved, by using a candidate gene, significance is likely with a lod score in excess of $+2 \cdot 00$.

\section{Discussion}

Distinguishing the different forms of neurofibromatosis is not merely an academic exercise: their natural history, and, therefore, management, are quite different. The patients presented here raise the question as to whether schwannomatosis is actually a distinct entity from NF2 or part of an extended phenotype.

SCHWANNOMA VERSUS NEUROFIBROMA

One of the problems in answering this question by reviewing of patients' case notes, was the loose use of terminology with respect to their tumours-we often found tumours reported as schwannoma but referred to in a clinician's letter as neurofibroma. The histological term is interchangeable with neurilemmoma, ${ }^{5}$ which it has now largely replaced. Although clinically spinal schwannomas and neurofibromas can appear similar radiologically and at operation, histologically they are quite distinct. Schwannomas are a pure growth of Schwann cells containing few if any other cell types, whereas a neurofibroma contains Schwann cells, fibroblasts, and mast cells and the axons are often seen running through the tumour, rather than around it as occurs in a schwannoma. ${ }^{12}$ Despite this, in some of our cases, histologists had reported tumours as neurofibromas, but review by an experienced neuropathologist as part of the study showed the lesions to be schwannomas. The importance of this distinction is that schwannomas do not occur in excess in NF1, but are the prominent feature of NF2. A review of 
patients with spinal nerve tumours ${ }^{13}$ showed that of 68 patients, 40 had a sporadic schwannoma, two had a sporadic neurofibroma, with 14 patients having NF1 and seven NF2. Of the patients with NF1 all had neurofibromas only, whereas six of seven patients with NF2 had schwannomas only. The remaining patient with NF2 had features of both types. A further five patients had either more than one schwannoma or a schwannoma and other CNS tumours. It could be argued that at least three of these patients had schwannomatosis.

\section{SCHWANNOMATOSIS}

Schwannomatosis or neurilemmomatosis has been proposed as a separate entity to NF1 and NF2. ${ }^{61415}$ This classification is made largely on the basis of an extensive Japanese literature and 35 cases were reviewed in $1984 . .^{14}$ Of 13 definite cases, seven had eighth nerve symptomatology highly suggestive of vestibular schwannoma, three patients were children, and the other three only in their 20 s. Of the four definite new cases reported by Shishiba et $a l^{14}$ one had bilateral vestibular schwannoma, two were only 8 and 13 years old and although one patient was 45 years old, no radiological exclusion of vestibular schwannoma was performed. Of the remaining 16 probable cases, nine had eighth nerve symptomatology, three were prepubertal, and one was 18 years old with evidence of intracranial disease. Only three patients were over the average age of presentation for vestibular schwannoma in NF2 (20-22 years $)^{1617}$ and all of these were in the pre-CT era. Shishiba et $a l^{14}$ reported an overall rate for eighth nerve tumour of 15 of 33 and it is highly likely that these patients represented new mutations for classic NF2. The type and range of skin lesions reported were identical with those occurring in NF2. ${ }^{16}$ It is also of note that the incidence of glioma in their report was identical to that found in large NF2 series. ${ }^{16}{ }^{17}$ A more recent report of two cases ${ }^{6}$ contained one clear case of NF2. This patient had bilateral vestibular schwannoma, typical intracranial calcification, ependymomas, and a trigeminal tumour. A rather spurious argument was made that this case lacked the other "cardinal" features of NF and therefore this precluded a diagnosis of NF2. The second case had multiple intracranial meningiomas and although CT of the auditory meatuses were normal the patient was only 20 years old. This patient would therefore fulfil our modified criteria for NF $2,{ }^{18}$ and we think it very likely she would go on to develop bilateral vestibular schwannoma. A further American patient aged 60 years with multiple neurilemmomas has been reported, but, there were insufficient clinical data to determine the context in which these tumours occurred. ${ }^{19} \mathrm{~A}$ more convincing recent report of 14 patients with schwannomatosis, who were carefully excluded as having NF2 (no vestibular schwannoma, cataracts, or meningioma) also identified this condition as being distinct from NF2. However, three of the patients were still very young and many others had very localised disease.
Most previous cases of schwannomatosis have been isolated; this report has clearly outlined autosomal dominant inheritance of a tendency to develop multiple schwannomas. This has also been reported by Riccardi ${ }^{4}$ and Shishiba et al. ${ }^{14}$ The question is whether this entity is distinct from NF2. One of the patients from Shishiba et al from the 1984 report ${ }^{514}$ has gone on to develop more classic NF2. The diagnosis of schwannomatosis relies heavily on exclusion of NF2 by the NIH criteria (table 1). ${ }^{1}$ These criteria rely on the presence of bilateral vestibular schwannoma or a family history. As $50 \%$ of people with NF2 are new mutations ${ }^{20}$ and at least $20 \%$ present initially with spinal or cutaneous tumours ${ }^{17}$ most, if not all, of the eight patients aged 16 years or under in Shishiba's review ${ }^{14}$ are likely to develop classic NF2. This is further borne out by our family $\mathrm{V}$, who for many years would have been considered a classic schwannomatosis family until bilateral vestibular schwannoma were diagnosed in two family members. It is therefore likely that the great majority of all the previous cases of schwannomatosis actually represent new mutations for NF2. It is possible that some patients may represent somatic mutations in whom the mutation in the NF2 gene has occurred postzygotically, but may still mean that a significant proportion of cells contains the mutation. This could mean that tumours may be confined to one part of the spine or skin for instance, such as in the study of MacCollin et al..$^{15}$ There is a good precedent for this "mosaicism" in NF1 where there are clear patients in whom only part of the body is affected and yet there may still be a risk of transmission to the offspring if the gonads are involved. ${ }^{5}$ None the less if the patient is young, a diagnosis of classic NF2 is still highly likely and even if they are old and vestibular schwannoma have been excluded on MRI, caution must be exercised about the risks of transmission.

Previous analysis of families with familial spinal neurofibromatosis found linkage to the NF1 locus in one family who also had cafe au lait patches, but exclusion in a second family without other corroborating features of NF1.21 There was insufficient information to assess linkage to the NF2 locus. These families are likely to be distinct from those exhibiting multiple schwannomas. The first family clearly had NF1 with spinal neurofibromas and therefore linkage at this locus was not surprising.

No single family member fulfils the NIH diagnostic criteria for NF1 or NF2 in five of the families reported here. Although at least one family member has developed a cranial nerve schwannoma in three of them. It is likely that the reliance on bilateral vestibular schwannoma as the sole diagnostic criteria for NF2 in sporadic cases has biased all reported cases, leading us to think that there is virtual complete penetrance of this disease feature in NF2. However, even in classic families there are often patients who do not develop vestibular schwannoma late into life. ${ }^{1822}$ The premise that vestibular schwannoma reaches full penetrance in NF2 would seem to be a false one. It 
is therefore possible that certain mutations in the NF2 gene, or in a closely linked gene predispose to a different pattern of tumours, with sparse cranial involvement, but many spinal and cutaneous tumours. In some families such as the five we have presented it may be possible to counsel on the basis of a lower risk of cranial tumours, but it would be dangerous to do so in isolated patients with multiple schwannomas. It is likely that there is still an increased risk of eighth nerve tumours in all these families.

We have found no evidence for exclusion of any of these families from the NF2 locus using linked and intragenic markers and indeed have generated a near significant lod score to support involvement of the NF2 gene. Coupled with the recent identification of a germline mutation in the NF2 gene in a 42 year old with schwannomatosis, ${ }^{23}$ and a 163 base pair deletion in another patient with multiple schwannomas, ${ }^{24}$ we think that, even in the families in which there would seem to be a schwannomatosis phenotype distinct from classic NF2, the causative mutation may well be in the NF2 gene. We have not as yet isolated a mutation in these families using single strand conformation polymorphism (SSCP) and heteroduplex analysis, but these methods have a relatively low success rate in identifying mutations in the NF2 gene. ${ }^{25}$ As mutation screening techniques of the NF2 gene $^{2627}$ improve it will soon be possible to determine whether there is a molecular basis for isolated and familial cases of schwannomatosis, when there is cranial sparing. An intriguing possibility has been raised by the differential expression of two isoforms of the NF2 protein in adult rat brain and spinal cord. ${ }^{27}$ Mutations which interfere with normal splicing of exon 16 to create the type 1 isoform could give rise to a form of the disease confined to the spine.

\section{Conclusions}

When an individual presents with a spinal tumour at a young age, or they develop multiple tumours, NF2 must be considered. It is important that the difference between neurofibroma and schwannoma is established and that cranial imaging is also performed. Our families suggest that a spinal form of NF is probably not a distinct disorder, but a variant of NF2. Only in families with an established pattern of spinal and cutaneous tumours and absence of cranial tumours is it possible to relax screening for vestibular schwannoma. Patients presenting at a young age with a spinal or cutaneous schwannoma or at any age with multiple schwannomas should still be screened for the development of cranial tumours. Although bilateral vestibular schwannoma will occur in most cases of NF2 this manifestation should no longer be thought of as the "hallmark" of the disease.

1 National Institutes of Health Consensus Development Conference Statement on Neurofibromatosis. Neurofibromatosis Research Newsletter 1987;3:3-6.

2 Rouleau G, Seizinger BR, Ozelius LG, et al. Genetic linkage analysis of bilateral acoustic neurofibromatosis to a DNA marker on chromosome 22 . Nature $1987 ; 329: 246-8$.

3 Seizinger BR, Rouleau GA, Ozelius LG, et al. Genetic linkage of von Recklinghausen neurofibromatosis to the nerve of von Recklinghausen neurofibromatosis to
growth factor receptor gene. Cell 1987;49:589-94.

4 Riccardi VM. Neurofibromatosis: phenotype, natural history and pathogenesis. Baltimore: John Hopkins University Press, 1992 .

5 Viskochil D, Carey JC. Alternate and related forms of the neurofibromatoses. In: Huson SM, Hughes RAC, eds. The neurofibromatoses. London: Chapman and Hall, 1994: 455-69.

6 Purcell SM, Dixon SL. Schwannomatosis. Arch Dermatol $1989 ; 125: 390-3$

7 Sambrook J, Fritsch EF, Maniatis T. Molecular cloning: a laboratory manual. 2nd ed. New York: Cold Spring Harbor Laboratory Press, 1989.

8 Weissenbach J, Gyapay G, Dib C, et al. A second generation linkage map of the human genome. Nature 1992;359: linkage map

9 Bourn D, Strachan T. Di-nucleotide repeat polymorphism at the NF2 gene. Hum Mol Genet 1994;3:1914.

10 Marineau C, Baron C, Delattre O, Zucman J, Thomas G, Rouleau GA. Dinucleotide repeat polymorphism at the D22S268 locus. Hum Mol Genet 1993;2:336.

11 Sainz J, Nachiporuk A, Kim U, Simon MI, Pulst SM. Carepeat polymorphism at the D22S430 locus adjacent to NF2. Hum Mol Genet 1993;2:2203.

12 Fisher ER, Vuzevski VD. Cytogenesis of schwannoma (neurilemoma), neurofibroma, dermatofibroma, and dermatofibrosarcoma as revealed by electron microscopy. $A m$ 7 Clin Pathol 1968;49:141-54.

13 Halliday AL, Sobel RA, Martuza RL. Benign spinal nerve sheath tumours. Their occurrence sporadically and in neu-

14 Shishiba T, Niimura M, Ohtsuka F, Tsuru N. Multiple cutaneous neurilemmomas as a skin manifestation of neucutaneous neurilemmomas as a skin manifestation of

rofibromatosis. F Am Acad Dermatol 1984;10:744-54.
15 MacCollin M, Woodfin W, Kronn D, Short MP. Schwannomatosis: a clinical and pathological study Neurology 1996;46:1072-9.

16 Evans DGR, Huson SM, Donnai D, et al. A clinical study of type 2 neurofibromatosis. $Q 7$ Med 1992;84:603-18.

17 Kanter WR, Eldridge R, Fabricant R, Allen JC, Koerber T Central neurofibromatosis with bilateral acoustic neuroma. Genetic, clinical and biochemical distinctions from peripheral neurofibromatosis. Neurology 1980;30:851-9.

18 Evans DGR, Huson SM, Donnai D, et al. A genetic study of type 2 neurofibromatosis: II guidelines for genetic counselling. $\mathcal{F}$ Med Genet 1992;29:847-52.

19 Izumi AK, Rosato FE, Wood MG. Von Recklinghausen's disease associated with multiple neurolemmas. Arch Dermatol 1971;104:172-6.

20 Evans DGR, Huson SM, Donnai D, et al. A genetic study of type 2 neurofibromatosis in the north west of England and the UK: I prevalence, mutation rate, fitness and confirmation of maternal transmission effect on severity. $7 \mathrm{Med}$ tion of maternal tran

21 Pulst SM, Riccardi VM, Fain P, Korenberg JR. Familial spinal neurofibromatosis: clinical and DNA linkage analysis. Neurology 1991;41:1923-7.

22 Evans DGR, Bourn D, Wallace A, Ramsden RT, Mitchel JD, Strachan T. Diagnostic issues in a family with late onset type 2 neurofibromatosis. F Med Genet 1995;32 $470-4$.

23 Honda $M$, Arai E, Sawada S, Ohta A, Niimura $M$ Neurofibromatosis 2 and neurilemmomatosis gene are identical. F Invest Dermatol 1995;104:74-7.

24 Schroder S, Mautner VF, Kluwe L. Genotyping proved neurofibromatosis type 2 in clinically non classifiable neurofibromatosis. Fifth European Neurofibromatosis Group Meeting. 1995; A37.

25 Merel P, Hoang-Xuan K, Sansom M, et al. Screening for germ-line mutations in the NF2 gene. Genes Chromosomes Germ-line mutations in

26 Rouleau GA, Merel P, Lutchman M, et al. Alteration in a new gene encoding a putative membrane-organizing procin causes neuro-fibromatosis type 2. Nature 1993:363; 515-21.

27 Troffater JA, MacCollin MM, Rutter JL, et al. A novel moesin-, ezrin-, radixin-like gene is a candidate for the neurofibromatosis 2 tumor suppressor. Cell 1993;72: 791-800.

28 Norton KK, Geist RT, Wright DE, et al. Expression of neurofibromatosis 2 isoforms in adult and embryonic tissues. Am $\mathcal{F}$ Hum Genet 1995;57:A149. 